\title{
Common Stock Put Options: Gambling Without A Penalty
}

J. Richard Anderson, (E-mail: jranderson@stonehill.edu), Stonehill College

\begin{abstract}
Companies have recently begun to speculate in their own stock by selling common stock put options. The subsequent exercise of these options often creates a loss of shareholder wealth that is not currently recognized due to antiquated accounting rules. This paper argues that it is clearly time for a change in the accounting treatment of these transactions.
\end{abstract}

\section{Introduction}

$\mathscr{I}$

$\mathrm{n}$ its September 30, 2002 quarterly report, Electronic Data Systems, Inc. (EDS) announced that in the past three months it had repurchased 5.4 million shares of its own common stock at an average price of $\$ 62.73$ per share. While the repurchase of treasury stock has become a commonplace event in the past decade, this transaction was not a normal one, since EDS's stock price never exceeded $\$ 44.00$ during the quarter and at one point dropped to a low of $\$ 10.09$. While specific transaction dates and purchase prices were unavailable, anyone who does the math will find that EDS paid \$101-284 million more than current market price to reacquire these shares. Facing troubles in their core business and a serious decline in free cash flow, EDS was forced to borrow \$225 million to finance the transaction. ${ }^{1}$ Since the company’s third quarter 2002 profit declined to $\$ 86$ million from $\$ 212$ million the previous year, financial statement readers might have pointed to this overpayment as one of the major causes. But they would be wrong. As reported in an EDS footnote, this transaction had no impact on profit:

"Amounts paid on the repurchase of the underlying shares, net of put premiums received of $\$ 15$ million, were recorded as a component of shareholder's equity." 2

What's wrong with accounting here? How can a company squander hundreds of millions of dollars of shareholder's money and not have it affect profit in any way? Perhaps we have allowed a long-held basic "truism" of accounting to blind us to economic reality here.

\section{Common Stock Put Options}

Why does a company borrow money to buy back its shares at twice the current market price? The answer is that they have gotten into the dangerous game of betting with investors on their own stock price by issuing "common stock put options" or "equity contracts." On the advice of investment bankers, some corporations have been selling "puts" for a fee of $\$ .50$ to $\$ 1.00$ per share, obligating themselves to buy back millions of common shares at a fixed price in the future. From the point of view of the buyer, these puts represent a low-cost insurance policy that would protect them from a fall in the company's stock price. Issuers supposedly benefit because in addition to the fees earned for selling the puts, they could "lock in" a purchase price for treasury shares that would then be used in executive stock option programs.

All this made good sense if the stock price kept increasing. But if the stock price fell sharply, as it did for EDS, the cost of making good on these insurance policies becomes significant. Regrettably, EDS was not alone here: Microsoft, Gillette, McDonald's, Maytag, Dell Computer, Clorox, and Eli Lilly have also placed large, losing bets on their own stock price by selling put options or equity contracts. 


\section{An Accounting Problem}

Clearly, investors will want to evaluate carefully managers who decide to make wagers on their own share price with corporate funds. However, antiquated accounting rules in this area prevent readers from understanding the size of the problem and the effect that it has on them.

The situation here parallels that of a firm purchase commitment for inventory. According to ARB 43, if a firm purchase commitment exists for inventory and the market price of the goods in question falls significantly, then this loss must be recognized immediately. ${ }^{3}$ However, if the firm commitment is to repurchase our own stock and the stock price declines before completion of the purchase, we do not recognize any loss. The justification for this treatment is the old adage that "corporations make no profits or losses dealing with their own stockholders," a venerable part of accounting folklore first put forward by the Committee on Accounting Procedure in 1938:

"Your committee believes that while the net asset value of the shares of common stock outstanding in the hands of the public may be increased or decreased by such purchase and retirement, such transactions relate to the capital of the corporations and do not give rise to corporate profits or losses." 4

Later the Accounting Principles Board reaffirmed this treatment:

"... the following should be excluded from the determination of net income or the results of operations under all circumstances: (a) adjustments or charges or credits resulting from transactions in the company's own capital stock...,

Perhaps the time has come to reexamine whether common stock put options should remain within the general framework of stockholder's equity accounting, which would prohibit the counting of any gains or losses on such transactions.

\section{Finding Economic Reality}

FASB Concepts Statement 6 specifically excludes any transactions with stockholders from net income or comprehensive income, ${ }^{6}$ but "put" options weren't in common use in the 1980's when the FASB was developing its conceptual framework. Thus we can't really look to professional standards for any real guidance here. Perhaps we should consider a common sense approach, which would say that any transaction which makes remaining shareholders wealthier should increase net income (or at least comprehensive income), and any transaction which hurts shareholders should result in decreased profits. If we accept this as a "gold standard," then all of the normal stockholder's equity transactions should not change profit. If we issue new stock at market price, pay a cash dividend, declare a stock split or a stock dividend, or even reacquire shares at market price, then we haven't hurt the wealth of whichever shareholders own the business after the transaction; each owner is in the same economic position vis-à-vis the company and other shareholders as they were before the event.

However, this is not true for the reacquisition of shares via the use of a put option or equity contract. In this case, the remaining owners are definitely worse off because the transaction took place. To confirm this, take a simple example: prices:

Suppose ABC Company has the following balance sheet just before repurchasing stock at above market

\begin{tabular}{|l|l|l|r|}
\hline & Liabilities & $\$ 2,000,000,000$ \\
\hline & Stockholder's Equity: & \\
\hline & Common Stock, 100,000,000 shares at $\$ 1$ par & $100,000,000$ \\
\hline & Additional Paid-in-Capital & $1,200,000,000$ \\
\hline & Retained Earnings & $\underline{1,700,000,000}$ \\
\hline Assets & $\$ 5,000,000,000$ & Total Stockholder's Equity & $\$ \underline{3,000,000,000}$ \\
\hline
\end{tabular}


The book value per share here is $\$ 30(\$ 3,000,000,000 / 100,000,000$ shares); assume that the market price of the stock is currently $\$ 50$. If investors holding put options force the company to buy back 10,000,000 shares of its stock at $\$ 90$, then its balance sheet becomes:

\begin{tabular}{|l|l|l|r|}
\hline & & Liabilities & \\
\hline & & Stockholder's Equity: & \\
\hline & & Common Stock, 100,000,000 shares at \$1 par & $100,000,000$ \\
\hline & & Additional Paid-in-Capital & $1,200,000,000$ \\
\hline & & Retained Earnings & $1,700,000,000$ \\
\hline & & Treasury Stock & $(900,000,000)$ \\
\hline & & Total Stockholder's Equity & $\$ 2,100,000,000$ \\
\hline Assets & $\$ 4,100,00,000$ & Total Liabilities \& Equity & $\$ 4,100,000,000$ \\
\hline
\end{tabular}

The book value per share thus falls to $\$ 23.33$ ( $\$ 2,100,000,000 / 90,000,000$ shares). What should happen to the market value per share? If $\mathrm{ABC}$ has just paid out a premium of $\$ 400$ million over current market value to repurchase these shares, then the remaining 90,000,000 outstanding shares have just lost $\$ 4.44$ of liquid assets per share. When the market learns of this transaction, share price should fall, just as it would if $A B C$ announced that it had settled a previously unannounced IRS lawsuit at a cost of $\$ 400,000,000$.

\section{See A Loss, Book A Loss}

In addition to the "loss of shareholder wealth" argument above, there are a number of other good reasons why these put contracts should be recognized as a loss and a liability:

(1) As soon as these investors "put" their options, they are no longer shareholders. Indeed, as the stock price began to dip appreciably below the option price, these people probably ceased to even think of themselves as shareholders. In other equity transactions (exercising stock options, converting bonds into stock, cash dividends, stock dividends, stock splits), the party involved is a common stockholder after the transaction is done. The only exception to this is a repurchase of stock, but if the repurchase is made at current market price, remaining stockholders have not lost any value. In a stock repurchase forced by a put option, we are not really dealing with a continuing stockholder.

(2) This is a cash loss - If ABC Company repurchases $10,000,000$ shares of its own stock at $\$ 90$ when the market price has fallen to $\$ 50$, it has paid out an extra $\$ 400,000,000$ in cash which did not purchase any appreciable benefit for its remaining shareholders. While this does not meet the FASB's definition of a loss, (since SFAC \#6 excludes transactions with owners), it does meet most reader's ideas of what a loss is - an outflow of assets without any benefits to owners.

(3) Put option contracts appear to create a liability under the SFAC definition: a "probable future sacrifice of economic benefits arising from present obligations of a particular entity to transfer asset in the future as a result of past transactions or events." ${ }^{\prime 7}$ Such a contract would qualify as a contingent liability with a high probability of becoming a cash outflow when the stock price drops below the put price.

\section{Time For A Change}

Put options or equity contracts were not a concern when the CAP, the APB and the FASB developed the definitions and standards that now govern stockholder's equity accounting. While the exclusion of transactions with owners from the income statement makes good sense for most common transactions, it doesn't work well here. In the case of EDS, management made a very unprofitable bet which cost stockholders hundreds of million of dollars, but the event had no impact on income. There is a legitimate question whether the resulting loss from holding firm common stock purchase commitments in a declining market should be part of net income or included only in comprehensive income, but it clearly belongs somewhere in the computation of profit. 
What we need is to narrow our definition of a stockholder- we should exclude from profit only transactions with people who remain stockholders after the event. Settling a common stock put option by purchasing shares at a premium price looks much more like a transaction with a creditor than with an owner and should be dealt with as the settlement of a debt at a loss, not as the simple repurchase of stock.

\section{Footnotes}

1. Spagat, E., and Gary McWilliams, "Leading the News: EDS Made Losing Bet on Its Stock --- Firm Borrowed \$225 Million To Unwind Obligations, Raising Slew of Concerns,” Wall Street Journal, September 25, 2002 , p. A3. 2. Electronic Data Systems Quarterly Report, September 30, 2002, p.14.

3. Committee on Accounting Procedure "A Restatement and Revision of Accounting Research Bulletins Nos 1-42 and Accounting Terminology Bulletin No 1 (originally issued 1939-1953)," Accounting Research Bulletin No. 43, (New York: AICPA, 1953), Chapter 4, Statement 10.

4. Ibid., Chapter 1B, Paragraph 7.

5. "Reporting the Results of Operations," Accounting Principles Board Opinion No.9, (New York: AICPA, 1966), Paragraph 28.

6. "Elements of Financial Statements," Statement of Financial Accounting Concepts No 6, (Stamford, Conn.: FASB, 1985), Paragraph 70.

7. Ibid., Paragraph 35. 